\title{
PENGARUH PENERAPAN E-GOVERNMENT PADA PEMBANGUNAN SMART CITY DI KABUPATEN SUMENEP
}

\author{
Nur Inna Alfiyah \\ Fakultas Ilmu Sosial dan Politik, Universitas Wiraraja \\ email: nurinna@wiraraja.ac.id
}

\begin{abstract}
Based on Presidential Instruction Number 3 of 2003 concerning National Policies and Strategies regarding E-government. Demand governments at various levels to take the necessary steps according to their respective duties, functions and authorities for the implementation of e-government development programs. To apply e-government in Sumenep Regency, the local government began to take steps in responding to the presidential decree issued by the central government by launching the g-online program. The g-online program is able to provide benefits to local government organizations in integrating public service systems. As technology and information are developing rapidly, government programs are undergoing renewal, with the birth of the smart city development program as a step towards strengthening the implementation of e-government in the regional government of Sumenep Regency. So this writing aims to answer how the influence of e-government in the construction of smart cities in Sumenep Regency. The method used in this research is an explanative descriptive method with the support of library or library data.
\end{abstract}

Keyword: public services; e-government; smart city.

\begin{abstract}
ABSTRAK
Berdasarkan Inpres Nomor 3 Tahun 2003 tentang Kebijakan dan Strategi Nasional tentang E-government. Menuntut pemerintah di berbagai tingkatan untuk mengambil langkahlangkah yang diperlukan sesuai tugas, fungsi dan kewenangan masing-masing guna terlaksananya program pengembangan e-governemnt. Untuk mengaplikasikan e-government di Kabupaten Sumenep, pemerintah daerah mulai mengambil langkah-langkah dalam menjawab inpres yang dikeluarkan pemerintah pusat dengan meluncurkan program g-online. Program g-online mampu memberikan manfaat pada organisasi pemerintah daerah dalam mengintegrasi sistem-sitem pelayanan publik. Seiring berkembang pesat nya teknologi dan informasi menjadikan program-program pemerintah mengalami pembaruan, dengan lahirnya program pembangunan smart city sebgai langkah pemantapan penerapan egovernment di dalam pemerintahan daerah Kabupaten Sumenep. Sehingga penulisan ini bertujuan untuk menjawab bagaimana pengaruh e-governemnt dalam pembangunan smart city di Kabupaten Sumenep. Metode yang digunakan dalam penelitian ini adalah metode deskriptif eksplanatif dengan dukungan data bersifat library atau kepustakaan.
\end{abstract}

Kata Kunci: pelayanan publik; e-government; smart city. 


\section{PENDAHULUAN}

Perkembangan teknologi dan informasi pada era globalisasi memberikan perubahan besar dalam tatanan masyarakat terutama dalam hal komunikasi dan pelayan publik di lingkungan pemerintah. perkembangan tersebut membawa dampak pada beralihnya sistem-sistem pelayanan tradisional yang based on paper administration atau pelayanan yang berbasis manual dengan menggunkan kertas berganti pada pelayanan berbasis elektronik. Hal ini kemudian mendorong lahirnya layanan informasi yang berbasis media elektronik dengan lahirnya e-governemnt sebagai jawaban dari perkembangan tekhnologi dan informasi. Pada sistem pelayanan publik pemerintah baik tingkat pusat hingga daerah secara bertahap mulai mengadaptasi konsep e-government dalam pelayanan publik nya. Pengembangan e-government di Indonesia diatur dalam Inpres Nomor 3 Tahun 2003 tentang Kebijakan dan Strategi Nasional tentang E-government. Inpres tersebut antara lain mengintruksikan kepada gubenur dan bupati/wali kota di seluruh Indonesia untuk mengambil langkah-langkah yang diperlukan sesuai tugas, fungsi, dan kewenangan masingmasing guna terlaksananya program pengembangan e-governemnt secara nasional (Kasiyanto dalam Mulyadi, 2016:242-243).

Berdasarkan definisi dari World Bank, e-governemnt adalah penggunaan teknologi informasi (seperti Wide Area Network, Internet dan Mobile computing) oleh pemerintah untuk mentransformasikan hubungan dengan masyarakat, dunia bisnis dan pihak yang berkepentingan. Dalam praktiknya, e-governemnt adalah penggunaan internet untuk melaksanakan urusan pemerintah dan penyediaan pelayanan publik yang lebih baik dan cara yang berorientasi pada pelayanan masyarakat. Sedangkan menurut Gronlund (2007) dengan melaksanakan e-government akan menghasilkan keuntungan dengan berkurangnya korupsi akibat dari meningktnya transpirasi di lingkungan pemerintah, peningkatan penerimaan negara dan pengurangan biaya. Disamping itu, implementasi e-government memberikan pelayanan tanpa adanya intervensi pegawai institusi publik, dan memangkas sistem antrian yang panjang hanya untuk mendapatkan suatu pelayanan yang sederhana. Selain itu e-government juga dimaksudkan untuk mendukung pemerintahan yang baik (Good Governence) (Mulyadi, 2016:244).

Dalam perkembangannya, implementasi e-government pada saat ini masih berfokus pada peneyediaan website dan layanan informasi saja. Sehingga banyak persepsi yang beranggapan bahwa ketika suatu instansi menyediakan website makas instansi terutama ditingkat daerah dianggap sudah menerapkan e-govenment. Padahal e-govenment sendiri tidak saja menampilkan informasi pemerintaha melalui website saja melainkan pemerintah juga dituntut untuk memupuk kerjasama dengan berbagai stakeholder yang ada di daerah dalam upaya mensukseskan e-government. Karena pelaksanaan e-government tidak bisa dikerjakan oleh pemerintah sendiri melainkn memerlukan dukungan dan sokongan dari berbagai pihak, baik masyarakat hingga swasta.

Suksesnya pengembangan e-government perlu ada dukungan dari berbagai elemen, dimana menurut Prof. Richardus Eko Indrajit (2013) ada 3 elemen tersebut; pertama, Dukungan (support), dukungan merupakan elemen pertama dan paling krusial yang harus dimiliki oleh pemerintah adalah keinginan (intent) dari berbagai kalangan pejabat publik dan politik untuk benar-benar menerapkan konsep e-government. Dimana keinginan tersebut bukan hanya sekedar mengikuti trend saja, sehingga untuk menerapkan implementasi program e-governemnet yang efektif harus dari pimpinan pemerintah yang berada pada level tertinggi (Presiden dan para pembatunya - Menteri) sebelum merambat ke level-level di bawahnya (Eselon 1, Eselon 2, Eselon 3, dan seterusnya). Yang dimaksud dengan dukungan di sini juga bukanlah hanya pada omongan semata, namun lebih kepada action yang dilakukan oleh pemerintah dalam mendukung e-government seperti 
pengalokasian sumber daya (manusia, finansial, tenaga, waktu, informasi, dan lain-lain). Pembangunan infrastruktur dan superstruktur pendukung agar tercipta lingkungan kondusif untuk mengembangkan e-government (seperti adanya Undang-Undang dan Peraturan Pemerintah). Serta disosialisasikannya konsep e-government secara merata, kontinyu, konsisten, dan menyeluruh kepada seluruh kalangan birokrat secara khusus dan masyarakat secara umum melalui berbagai cara kampanye yang simpatik.

Kedua, Kapasitas (capacity) merupakan elemen yang berbasis pada unsur kemampuan atau keberdayaan dari pemerintah setempat dalam mewujudkan e-government seperti ketersediaan sumber daya finansial, ketersediaan infrastruktur teknologi informasi yang memadai serta ketersediaan sumber daya manusia yang memiliki kompetensi dan keahlian yang dibutuhkan agar penerapan e-government dapat sesuai dengan asas manfaat yang diharapkan. Ketiga, Nilai (value), pada elemen ini pemerintah di dalam meng implementasikan e-government pemerintah dituntut untuk benar-benar memperhatikan apa yang dibutuhkan masyarakat, karena tanpa memperhatikan kebutuhan tersebut akan mendatangkan bumerang sendiri bagi pemerintah. Sehingga dalam menentukan besar tidaknya manfaat yang diperoleh dengan adanya e-government bukanlah kalangan pemerintah sendiri, melainkan masyarakat dan mereka yang berkepentingan (demand side). Ketiga elemen tersebut merupakan kunci bagi suksesnya implementasi e-government di dalam pemerintahan baik di tingkat pusat hingga tingkat daerah. Sehingga hal tersebut menuntut tiap tingkatan pemerintah yang ada di negara ini untuk mulai merubah sistem kerja pelayanan publik yang ada dengan berbasis elektronik. Dimana berdasarkan tiga elemen yang dijelaskan tersebut, pemerintah menjadi faktor kunci penentu keberhasilan pelaksanaan e-government di daerah masing-masing.

Kabupaten Sumenep sebagai salah satu pemerintahan yang ada di kepulauan madura tentu tidak bisa menghindari upaya-upaya penerapan e-government di dalam pemerintahan dan pelayanan publik. Ditambah lagi dengan tuntutan pengadaan fasilitas pelayanan yang layak serta tidak berbelit-belit menjadikan keharusan bagi pemerintah Kabupaten Sumenep untuk menerapkan e-government. Pemerintah Kabupaten Sumenep sendiri telah merintis penerapan e-government sejak tahun 2002, melalui program yang bernama g-online (http://sumenepkab.go.id). Dari tahun 2002 hingga tahun 2010, program g-online mampu memberikan dampak yang signifikan dalam pengembangan e-government. Akan tetapi dengan berbagai faktor yang ada terutama penegmbangan hal teknis dan infrastruktur yang tidak diimbangi dengan startegi dan regulasi yang maksimal, program tersebut mengalami kegagalana dan terbengkalai. Hingga kemudian pada pemilihan kepala daerah terbaru, upaya-upaya pemulihan terkait implementasi e-governemnt dilakukan secara bertahap dengan pertama tama mengubah sistem ditiap organisasi pemerintah daerah menggunakan sistem berbasis elektronik. Hingga kemudian muncul masterplan smart city pemerintah kabupaten sumenep, hal in juga diperkuat dari komitmen pemerintah daerah yang tercantum dalam Peraturan Bupati 52 Tahun 2017 tentang pelaksanaan $e$ government di lingkungan pemerintah. Munculnya masteplan smart city Kabupaten Sumenep, merupakan bentuk keberlanjutan dari komitmen pemerintah dalam meng implementasikan e-government dilingkunan pemerintah Sehingga dengan penjelasan tersebut, artikel ini bertujuan untuk menjelaskan pengaruh penerapan e-governemnt dalam pembangunan smart city di Kabupaten Sumenep.

\section{METODE PENELITIAN}

Metode yang digunakan dalam penelitian ini adalah deskriptif eksplanatif, dimana deskriptif merupakan suatu metode dalam meneliti suatu kondisi, suatu obyek dan peristiwa yang terjadi pada masa sekarang. Sedangkan menurut Whitney (1960) dikutip oleh 
Mohammad Nazir, mengatakan bahwa penelitian drskriptif yaitu mempelajari masalahmasalah dalam masyarakat, serta tata cara hubungan, kegiatan, serta proses-proses yang sedang berlangsung dan pengaruh-pengaruh dari suatu fenomena (Nazir, 1988:63). Sementara eksplanatif, menjawab tentang mengapa sebuah situasi atau kondisi itu terjadi. Penggunaan dua metodologi ini untuk menawarkan penjelesan yang lebih konfrehensif mengenai tema penelitian. Sebuah penelitan sulit dijelaskan tanpa deskripsi, sebaliknya, diskripsi tanpa penjelasan yang masuk akal tidak menarik (G. King dkk,1994:34). Sifat dari penelitian ini bersifat literer dengan menggunakan tinjauan pustaka dan bahan-bahan tertulis dalam mendukung penulisan ini.

\section{HASIL DAN PEMBAHASAN}

Penerapan e-government di Kabupaten Sumenep mulai di rintis sejak tahun 2002, dengan diterapkannya program g-online yang bertujuan untuk memudahkan integrasi antara organisasi pemerintah daerah (OPD). Ini terlihat dari mulai tersedianya jaringan yang sudah terintegrasi antar OPD melalui jaringan internet, disamping itu tiap OPD mulai menciptakan website-website resmi yang berkaitan dengan pelayanan masing-masing OPD. Perintisan e-governemnt melalui program g-online tidak berjalan dengan baik dikarenakan banyak terkendala, mulai dari sistem jaringan, kurangnya penguasaan tekhnologi oleh aparatur pemerintah, sehingga pada tahun 2010 program tersebut mulai vacum. Sehingga pada pergantian pemerintahan periode berikutnya program ini kemudian dimasukkan dalam Rencana Pembangunan Jangka Menengah Daerah (RPJMD) yang diaktualisasikan dalam agenda rancangan rencana strategi dinas komunikasi dan informasi Kabupaten Sumenep melaui pengembangan jaringan g-online.

Masuknya pengembangan e-government dalam berbagai rencana pembangunan di Kabupaten Sumenep, menjadikan tiap organisasi pemerintahan yang ada mulai merevolusi sistem pelayanan publik mereka dengan menggunakan sistem yang berbasis elektronik. Hal ini kemudian mendorong tiap organisasi pemerintah daerah untuk melakukan inovasi terkait program-program unggulan yang akan ditawarakan kepada masyarakat dengan tujuan memberikan kemudahan dalam mengakses dan mendapatkan informasi bagi masyarakat. Upaya-upaya implementasi dan pengembangan e-government bagi pemerintah Kabupaten Sumenep mendapatkan angin segar meskipun program g-online yang di terapkan tidak sepenuhnya berjalan baik. Angin segar tersebut datang dari adanya penghargaan bagi pemerintah Kabupaten Sumenep dengan berhasil menjadi juara terbaik II pada penghargaan penerapan e-govenment tahun 2009 di tingkat kota kecil (http://sumenepkab.go.id/). Hal tersebut menjadi motivasi tersendiri bagi pemerintah daerah untuk semakin mengembangkan e-government dalam berbagai tingkatan lapisan baik pemerintah maupun di tingkat masyarakat.

Selain G-Online, di tahun 2014, Kabupaten Sumenep mencanangkan 'Sumenep Go Smart city'. Untuk mewujudkannya, pemerintah telah merancang penunjang berupa website kabupaten yang terintegrasi antara OPD untuk menyajikan informasi kependudukan, ketenagakerjaan, sistem informasi perizinan, pendidikan, jaring pengaman sosial, informasi kesehatan, pelaporan masyarakat, pajak daerah, e-procurement, dan e-surat. Selain itu, Kabupaten Sumenep sudah terpasang 25 CCTV. Kerjasama dengan provider juga dilakukan untuk menunjang jaringan internet hingga Pulau Sapeken (http://www.sumenepkab.go.id). Sampai saat ini, Kabupaten Sumenep telah memiliki 30 aplikasi atau sistem informasi dengan kondisi aktif, sebagai berikut: 
Tabel 1.

Aplikasi atau Sistem Informasi Kabupaten Sumenep

\begin{tabular}{|c|c|c|}
\hline No & Ketegori & Nama \\
\hline & Sistem informasi & 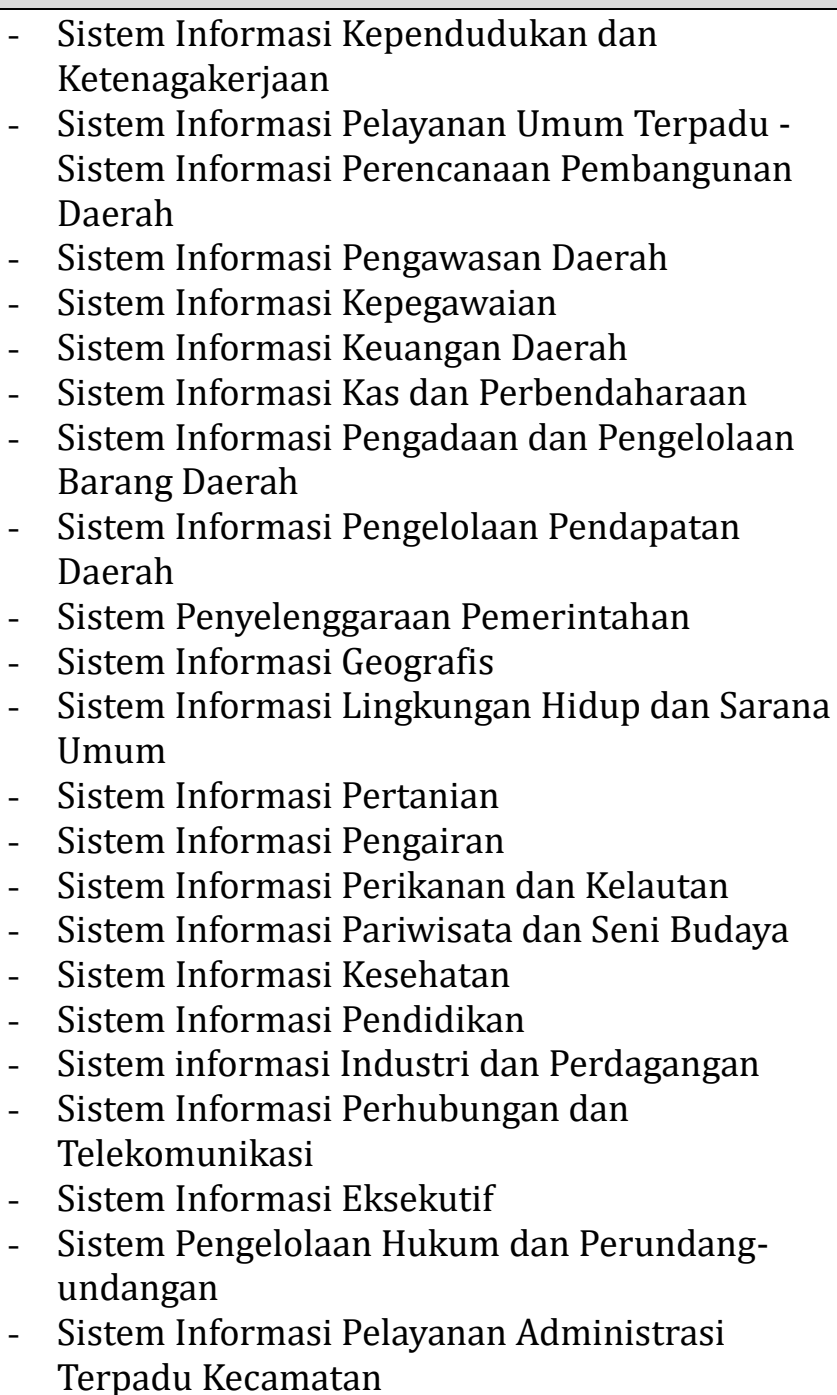 \\
\hline 2. & Aplikasi & $\begin{array}{l}\text { - Hi Sumenep } \\
\text { - mFish } \\
\text { - E-Finance } \\
\text { - E-Surat } \\
\text { - E-government }\end{array}$ \\
\hline
\end{tabular}

Berkembangnya sistem informasi dan aplikasi di Kabupaten Sumenep kemudian mendorong pemerintah untuk semakin mengembangkan sistem berbasis teknologi yang terintegrasi dalam berbagai lapisan terutama masyarakat dengan memunculkan master plan pembangunan smart city.

\section{E-government Sebagai Fondasi Pengembangan Smart city}

Secara definisi, Smart city adalah kota yang dapat mengelola semua sumberdaya secara efektif dan efisien dalam menyelesaikan berbagai tantangan, menggunakan solusi inovatif, terintegrasi dan berkelanjutan. Pengelolaan tersebut semata-mata untuk meningkatkan kualitas hidup warga kota. Dari definisi tersebut, ciri solusi dalam Smart city yaitu berupa pemikiran-pemikiran baru, terintegrasi, antar lembaga pemerintah hingga 
lembaga non-pemerintah, responsif terhadap persoalan kota serta solusi yang dirancang untuk menjadi solusi berkelanjutan, bukan hanya solusi sesaat (Pahlevi, 2017).

Pengembangan smart city merupakan fondasi dari pelaksanaan e-government, dimana e-government dan smart city memiliki tujuan untuk memaksimalkan pelayanan kepada warga masyarakat dengan bertumpu pada prinsip keterkaitan dan kerjasama dari beragam elemen terkait. Sebagaimana dijelaskan oleh Menteri Pendayagunaan Aparatur Negara Reformasi Birokrasi (Menteri PANRB) Syafruddin dalam keterangan tertulisnya, Senin (22/4/2019);

"Membangun e-Goverment akan mendorong terciptanya Smart city dengan menghadirkan tata kelola pemerintahan dan pelayanan publik yang semakin adaptif sehingga mampu menopang berbagai kebijakan publik yang strategis dalam membangun kemajuan negara". (Chrisbiyanto, 2019. https://ekbis.sindonews.com).

Pengembangan smart city sendiri di Kabupaten Sumenep di dasari dari masterplan Kelembagaan Birokrasi Berbasis Teknologi Informasi Kabupaten Sumenep Tahun 20162021. Selain itu, komitmen Pemerintah Kabupaten Sumenep dalam hal tata kelola pemerintahan juga terlihat dengan adanya Peraturan Bupati Kabupaten Sumenep Nomor 52 Tahun 2017 tentang Pelaksanaan dan Pengembangan E-government di lingkungan Pemerintah Kabupaten Sumenep, Keputusan Bupati Nomor 188/279/KEP/435.012/2017 tentang Pelaksanaan E-government, dan Keputusan Bupati Nomor 188/88/KEP/435/012/2018 tentang Panitia Pelaksana Pengembangan Jaringan G-Online. Peraturan Kepala Daerah dan Keputusan Kepala Daerah tersebut menjadi legitimasi organisasi perangkat daerah dalam melaksanakan pelayanan publik yang baik dan efisien (http://www.sumenepkab.go.id/).

Merujuk pada 3 elemen penentu kesuksesn penerapan e-govenment oleh Indrajit (2013) yang terdiri dari dukungan (support), kapasitas (capacity), serta nilai (value). Ketiga elemen tersebut menempatkan pemerintah sebagai pioner dalam mengalokasikan sumber daya, pembangunan infrastruktur dan memperhatikan apa yang dibutuhkan masyarakat, karena tanpa memperhatikan kebutuhan tersebut akan mendatangkan bumerang sendiri bagi pemerintah. Sehingga dalam menentukan besar tidaknya manfaat yang diperoleh dengan adanya e-government bukanlah kalangan pemerintah sendiri, melainkan masyarakat dan mereka yang berkepentingan (demand side). Ketiga elemen tersebut juga menjadi dasar syarat dari terbentuknya pembangunan smart city di Kabupaten Sumenep, dimana menurut masterplan yang telah dikeluarkan oleh pemerintah setidaknya terdapat beberapa analisis yang lakukan oleh pemerintah daerah guna mengukur kesiapan kabupaten untuk menerapkan smart city. Analisis tersebut meliputi analisis terkait sumeber daya manusia (SDM), analisis kualitas sumber daya pemerintah, analisis kapasitas keuangan daerah, analisis kesiapan infrastruktur fisik daerah, kesiapaan infrastruktur digital daerah, analisisi kesiapan infrastruktur sosial daerah, analisis kebijakan kabupaten sumenep, analisis kesiapan kelembagaan daerah, analisis kesiapan organisasi masyarakat Kabupaten Sumenep (http://www.sumenepkab.go.id). Adanya analisis tersebut menunjukkan bahwa dalam pembangunan smart city dilakukan tidak hanya berdasar pada kebijakan yang dikeluarkan oleh pemerintah saja, melainkan harus melihat kesiapan dari berbagai elemen yang ada di Kabupaten Sumenep dengan berbagai pertimbangan dampak baik dan buruknya terhadap masyarakat.

Upaya pemerintah Kabupaten Sumenep menuju smart city dimulai pada tahun 2017, ketika masuk dalam 50 kota terpilih untuk mengembangkan smart city oleh Kementerian Komunikasi dan Informatika RI sebagai kelanjutan 25 Kabupaten/Kota terpilih di tahun 2017. Terpilihnya Kabupaten Sumenep menjadi bagian dari program smart city pemerintah pusat bukanlah hal yang mudah sebab ada beberapa parameter yang harus terpenuhi antara 
lain (http://sumenepkab.go.id): 1. Kondisi keuangan daerah 2. Peringkat dan status kinerja penyelenggara pemerintah daerah 3. Indeks kota berkelanjutan 4. Dimensi pembangunan pemerataan 5. Kewilayahan serta indeks kota hijau. Pada tahun 2018, upaya perealisasian smart city mulai digodok oleh pemerintah dengan lahirnya masterplan smart city Kabupaten Sumenep tahun 2019-2028. Dalam masterplan ini dipaparkan visi dan sasaran smart city Kabupaten Sumenep, dengan didukung strategi pembangunan smart city yang meliputi; smart governance, smart branding, smart economy, smart living, smart society, smart environment (Alfiyah, 2019. Diakses di http://ejournal.uniramalang.ac.id).

Disamping itu pada pmebangunan smart city memerlukan adanya visi yang dilandasi dengan payung hukum pemerintah agar pada pelaksanaanya tidak terjadi kecurangan dan merugikan pihak-pihak tertentu. Sehingga visi smart city Kabupaten Sumenep disusun berdasarkan dokumen RPJM Kabupaten Sumenep 2016-2021, RPJM Provinsi Jawa Timur 2014-2019, RPJM Nasional 2015-2019, agenda prioritas pembangunan pemerintah pusat, harapan warga masyarakat, dan pernyataan kepala daerah Kabupaten Sumenep.Visi Pembangunan smart city Kabupaten Sumenep adalah "Mewujudkan Sumenep Makin Sejahtera, Cerdas, Inovatif, dan Berdaya Saing Melalui Optimalisasi Pemanfaatan TIK".

Visi smart city Kabupaten Sumenep terbagi menjadi tiga bagian. Tiga bagian tersebut yaitu bagian tujuan, bagian pendekatan dalam mencapai tujuan, dan bagian waktu untuk mencapai visi tersebut. Sumenep Makin Sejahtera, Cerdas, Inovatif, dan Berdaya Saing merupakan bagian visi yang menyatakan tujuan akhir smart city. Sejahtera yaitu mandiri dengan memanfaatkan segala potensi lokal yang ada dan taraf hidup yang baik. Sumenep sejahtera juga merupakan turunan dari visi RPJM Sumenep 2019, RPJP Sumenep 2025, RPJM Provinsi 2019, dan RPJM Nasional 2019. Cerdas yaitu masyarakat yang memiliki wawasan kedaerahan, kemampuan teknologi informasi dan komunikasi, dan turut andil dalam pembangunan Kabupaten Sumenep. Inovatif adalah penggunaan teknologi informasi dan komunikasi dalam menyelesaikan permasalahan Sumenep terkait pelayanan public, pembangunan ekonomi dan sosial. Berdaya Saing adalah Kabupaten Sumenep memiliki kemampuan dalam mengelola sumber daya daerah secara efektif dan efisien sehingga mampu bersaing dengan daerah lainnya baik skala daerah, provinsi, nasional, maupun internasional. Dalam mencapai tujuan Sumenep yang sejahtera dilakukan pendekatan Melalui Optimalisasi Pemanfaatan TIK (http://www.sumenepkab.go.id). Guna mencapai visi smart city, pemanfaatan teknologi dan informasi menjadi salah satu hal yang tidak bisa di hindarkan dalam pembanguna smart city. Hal ini juga dilandasi dari masuknya era revolusi industri 4.0 yang menuntut pemanfaatan teknologi informasi dan komunikasi menjadi keharusan dalam mengikuti perkembangan. Sehingga sistem informasi dan aplikasi yang dimilki oleh Kabupaten Sumenep sebagai sarana dalam peningkatan pelayanan publik, harus selalu terbarukan sesuai dengan tuntutan dan perkembangan teknologi di era 4.0.

\section{KESIMPULAN}

Seiring berkembangnya pengetahuan dibidang tekhnologi dan informasi menuntut pemerintah untuk semakin benar-benar meng implementasikan e-govenment sesuai dengan Intruksi presiden (Inpres) Nomor 3 Tahun 2003 tentang Kebijakan dan Strategi Nasional tentang E-government. Inpres tersebut antara lain mengintruksikan kepada gubenur dan bupati/wali kota di seluruh Indonesia untuk mengambil langkah-langkah yang diperlukan sesuai tugas, fungsi, dan kewenangan masing-masing guna terlaksananya program pengembangan e-governemnt secara nasional. Implementasi e-government yang terjadi di

Kabupaten Sumenep melalui g-online menjadi pioner dari lahirnya pemerintahan terintegrasi dengan menggunakan sistem yang berbasis elektronik. Hal ini kemudian dilanjutkan dengan penegmbangan smart city sebagai jawaban dari perkembangan pesat $e$ - 
government di daerah. Landasan-landasan pembangunan smart city tersebut tidak lepas dari fungsi dan ketentua yang ada dalam e-government. Sehingga bisa dikatakan pembangunan smart city di Kabuaten Sumenep tidak bisa dilepaskan dari pengaruh penerapan $e$ government dalam pemerintahan daerah.

\section{DAFTAR RUJUKAN}

Alfiyah, Nur Inna (2019), “Upaya Peningkatan Daya Tarik Wisata di Kabupaten Sumenep melalui Smart city System", Journal of Governance Innovation Volume 1, Number 1. Diakses di http://ejournal.uniramalang.ac.id/index.php/JOGIV/article/download/ 295/183/

Chrisbiyanto, Anton. (2019), "E-Govenrment Akan Topang Pengembangan Smart city". Diakases di https://ekbis.sindonews.com/read/1397940/34/e-government-akantopang-pengembangan-smart-city-1555939730

G. King, R. Keohane \& S. Verba (1994), "Designing Social Inquiry: Scientific Inference in Qualitative Research", Princeton University Press, New Jersey, , p. 34.

Gronlund, Ake (2007), Electronic Government, pada: Anttiroiko, Ari-Veiko and Matti Malkia (eds.), Encyclopedia of Digital Government, Volume I, Hershey: Idea Group Reference.

Indrajit, Richardus Eko (2013), Elemen Sukses Pengembangan E-Governemnet, E-Artikel Sistem dan Teknologi Informasi, Nomor: 233. Dikses di https://www.academia.edu/14352712/Elemen_Sukses_Pengembangan_Egovernment, 23 September 2019.

Infokom (2006), "G-On Line Pemerintah Kabupaten Sumenep Masuk Nominasi 10 Terbaik Di Indonesia". Diakses di http://sumenepkab.go.id/berita/baca/g-on-linepemerintah-kabupaten-sumenep-masuk-nominasi-10-terbaik-di-indonesia

Master Plan Smart city Kabupaten Sumenep 2019-2018. Diakses di http://www.sumenepkab.go.id/uploads/documen/buku/12052018-lap-akhirbuku-1-final.pdf

Mulyadi, Deddy (2016), Studi Kebijakan Publik dan Pelayanan Publik.Bandung: Alfabeta Nazir Mohammad (1988), Metode Penelitiam, Jakarta: Ghalia Indonesia

Pahlevi, Gilang Audi (2017), “Guru Besar ITB, Prof Suhono, Jabarkan Konsep Kota Cerdas sebagai Solusi Masalah Perkotaan”. Diakses di https://www.itb.ac.id/news/read/56387/home/guru-besar-itb-prof-suhonojabarkan-konsep-kota-cerdas-sebagai-solusi-masalah-perkotaan

Pemkab (2010), "E-government Diharapkan Mampu Berikan Pelayanan Publik Terbaik". Diakses di http://sumenepkab.go.id/berita/baca/e-government-diharapkanmampu-berikan-pelayanan-publik-terbaik 